\title{
PENJATUHAN SANKSI PIDANA TERHADAP PENYEBARAN KONTEN VIDEO PORNO MENGENAI PENCABULAN ANAK DI BAWAH UMUR MELALUI CYBER / DUNIA MAYA
}

\author{
Lalu Abi Yu'lla Maulana \\ ( Mahasiswa Fakultas Hukum Universitas Tarumanagara ) \\ (Email: abiyula9@gmail.com)
}

\section{Metty Rachmawaty}

(Corresponding Author)

(Dosen Hukum Pidana Fakultas Hukum Universitas Tarumanagara, Meraih Sarjana Hukum dari

Fakultas Hukum Universitas Trisakti, Magister Hukum dari Fakultas Hukum Universitas

Tarumanagara, Doktor Hukum dari Fakultas Hukum Universitas Trisakti)

\begin{abstract}
The unlimited use of Information Technology (IT), has made cybercrime accessible by both adults and minors. Technology can be very useful for daily needs, yet on the other hand, it also can be abused by certain parties including minors (underaged children). The purpose of this study is to examine law enforcement of cybercrime in Indonesia as well as forms of cybercrime that are able to be performed by underaged children. The method used by the author for this journal is normative legal research method. In this case of cybercrime committed by children under age, law enforcement should involves competent authorities such as psychologists, social supervisor, or other experts so no one makes wrong or bad decision for the children. After the proccess, parents of children that involved, should be required to closely supervise their children usage of IT.
\end{abstract}

Keywords: Pornography, Information Technology, Cybercrime. 


\section{PENDAHULUAN}

\section{A. Latar Belakang}

Dari ruang lingkup kekerasan seksual, mengenal adanya pencabulan, yaitu segala perbuatan melanggar kesusilaan (kesopanan) atau perbuatan yang keji, semuanya itu dalam lingkungan nafsu birahi, misalnya: ciuman, meraba-raba bagian kemaluan, meraba-raba buah dada, dan termasuk pula bersetubuh. ${ }^{1}$ Meskipun berbagai upaya telah dilakukan, namun disadari sepenuhnya bahwa di dalam masyarakat masih banyak anak yang memerlukan upaya perlindungan khusus. Selama ini program-program yang ditujukan pada anak masih belum menyentuh semua lapisan dalam masyarakat. Banyak pihak belum menyadari keberadaan anak sebagai aset bangsa yang perlu dilindungi dan dijamin hak-haknya dalam meniti masa depannya. ${ }^{2}$

Dalam keluarga yang ideal (lengkap) maka ada dua individu yang memainkan peranan penting yaitu peran ayah dan peran ibu. Secara umum peran ibu adalah, memenuhi kebutuhan biologis dan fisik, merawat dan mengurus keluarga dengan sabar, mendidik, mengatur dan membimbing anak, serta menjadi contoh dan teladan bagi anak. Secara umum peran ayah adalah sebagai pencari nafkah, menjadi suami yang penuh perhatian, memberi rasa aman, berpartisipasi dalam pendidikan anak, sebagai pelindung atau tokoh yang tegas, bijaksana, dan mengasihi keluarga, karenanya orangtua berkewajiban mendidik dan membimbing anak. ${ }^{3}$

Kebutuhan terhadap informasi merupakan sesuatu yang amat penting.Karena besarnya kebutuhan tersebut, terjadilah perkembangan di bidang teknologi informasi. Pesatnya perkembangan ini pada akhirnya menghasilkan suatu jaringan yang dikenal dengan nama cyberspace yang merupakan suatu teknologi yang berisikan kumpulan informasi yang dapat

\footnotetext{
${ }^{1}$ R. Soesilo, Kitab Undang-Undang Hukum Pidana (KUHP) Serta Komentar-komentarnya Lengkap Pasal Demi Pasal, (Bogor: Politeia, 1995), hlm. 29.

2 Sholeh Soeaidy dan Zulkhair. Dasar Hukum Perlindungan Anak. (Jakarta: CV.Novindo Pustaka Mandiri,2001),hlm. 1

${ }^{3}$ Singgih D.Gunarsa, Psikologi Perkembangan Anak dan Remaja, (Jakarta: BPK Gunung Mulia,2002) hal. 35
} 
diakses oleh semua orang dalam bentu jaringan-jaringan komputer yang disebut jaringan internet. Keberandaan cyberspace tersebut memberikan pengaruh yang besar terhadap berbagai bidang kehidupan. Pengaruh tersebut tidaklah selalu berdampak positif tetapi juga bisa berdampak negatif. Salah satu dampak negatif terwujudnya dengan adanya tindak pidana yang dilakukan dalam cyberspace yang dikenal dengan cybercrime.

Cybercrime atau apabila yang diterjemahkan dalam bahasa Indonesia sebagai tindak pidana dunia maya bukanlah hal yang mudah untuk diselesaikan. Hal ini dikarenakan cybercrime sebagai suatu jenis kejahatan merupakan suatu tindakan yang dilakukan di dalam dunia yang tidak mengenal batas wilayah hukum dan kejahatan tersebut dapat terjadi tanpa perlu adanya suatu interaksi langsung antara pelaku dengan korbannya. ${ }^{4}$ Sehingga dapat dikatakan, bahwa ketika suatu kejahatan cyber terjadi, maka semua orang dari berbagai negara yang dapat masuk ke dalam dunia cyber dapat terlibat di dalamnya, entah itu sebagai pelaku (secara langsung atau tidak langsung), korban, ataupun hanya sebagai saksi.

Untuk mengatasi atau setidaknya mengurangi masalah cyber crime ini, banyak negara-negara di dunia yang mencoba melakukannya dengan membuat suatu pengaturan terhadap kejahatan tersebut yang dikenal dengan nama cyberlaw. ${ }^{5}$ Dalam era globalisasi, khususnya dalam hal perkembangan di berbagai bidang kehidupan, masyarakat Indonesia juga mendapatkan pengaruh dari cyberspace. Oleh karenanya tidaklah mengherankan bila mulai bermunculan kasus-kasus kejahatan yang berhubungan dengan cybercrime. ${ }^{6}$

Pada awal munculnya berbagai kasus yang berkaitan dengan cyber crime di Indonesia pengaturan terhadap tindakan-tindakan yang

\footnotetext{
${ }^{4}$ Maskun, Kejahatan Siber Cyber Crime, (Jakarta:Prenada Media Group 2013), hlm.48

${ }^{5}$ https://www.google.co.id/search?client=ms-androidsamsung\&q=ur.it.t/kamal/the+law+of+cyberspace\&spell=1\&sa=X\&ved=0ahUKEwj_6IDI6fbaAh UL148KHSY9C1AQBQghKAA\&biw=360\&bih=612

${ }^{6} \mathrm{https}$ ://tekno.kompas.com/read/2008/07/24/07303570/kejahatan.cyber.tinggi.polisi. menerima.laporan.dari.17.negara
} 
berhubungan dengan cyber crime tersebut merupakan masalah yang sangat sulit ditangani oleh Indonesia, diantaranya terkait dengan hal-hal berikut:

1. Suatu tindakan yang dilakukan di dalam dunia yang tidak mengenal batas wilayah hukum dan kejahatan tersebut dapat terjadi tanpa perlu adanya suatu interaksi langsung antara pelaku dengan korbannya;

2. Belum tersedianya perangkat hukum atau peraturan perundangundangan yang ada di Indonesia. Sehingga dengan demikian, walaupun terjadi suatu tindakan yang sebetulnya kejahatan meskipun dilakukan didalam dunia maya/cyberspace, namun karena adanya asas legalitas maka di Indonesia tindakan tersebut tidak dapat di anggap sebagai suatu tindakan pidana;

3. Sistem pembuktian pidana di Indonesia dalam pasal 184 Kitab Undangundang Hukum Acara Pidana belum mengenal istilah bukti elektronik (digital evidence) sebagai bukti yang sah.Sehingga sulit melakukan pembuktian terhadap kejahatan-kejahatan yang berhubungan dengan cyber crime di Indonesia.

Dalam perkembangannya lahirlah suatu peraturan perundang-undangan yang memiliki fungsi sebagai suatu cyberlaw di Indonesia,yaitu Undangundang Nomor 11 Tahun 2008. ${ }^{7}$ Keluarga merupakan lingkungan hidup pertama dan utama bagi setiap anak. Didalam keluarga anak mendapat ransangan, hambatan, dan pengaruh yang pertama dalam pertumbuhan dan perkembangannya, baik biologis maupun psikologis. Didalam keluarga, anak juga mempelajari norma atau aturan dalam hidup bermasyarakat. Melalui kehidupan dalam berkeluarga, anak dilatih tidak hanya mengenal norma tetapi juga menghargai dan mengikuti norma-norma dan pedoman hidup bermasyarakat. Seringkali anak mengenal dan meniru model-model dari orangtua sebagai anggota masyarakat. ${ }^{8}$

${ }^{7}$ Undang-Undang Informasi dan Transaksi Elektronik (atau yang dikenal dengan UndangUndang ITE)disahkan pada tanggal 21 April tahun 2008 memiliki 13 Bab dan 54 Pasal memberikan pengaturan dalam bidang informasi teknologi terutama dalam ruang lingkup cyberspace

${ }^{8}$ Kartini Kartono, Peran Orang Tua dalam Memandu Anak, (Jakarta: Rajawali Press, 1992) hal.27 
Imam Ghazali mengatakan bahwa anak itu merupakan amanat bagi kedua orangtuanya, hatinya akan suci dan bersih jika terus menerus diajarkan kebaikan, dan anak akan tumbuh dengan kebiasaan yang baik. ${ }^{9}$

Ada pemikiran bahwa para anak dan remaja adalah tunas-tunas harapan bangsa yang akan melanjutkan eksistensi nusa dan bangsa Indonesia selama-lamanya. Jadi memberikan perlindungan pada para anak/remaja adalah sesuatu yang wajar dan merupakan tanggung jawab kita bersama. Selain itu perlindungan ini merupakan pula hak asasi mereka. Kata-kata kita bersama disini berarti juga :tanggung jawab para anak/remaja itu sendiri dalam batas- batas tertentu dan sesuai dengan kemampuan bertanggung jawab masing-masing (rasa tanggung jawab pada diri sendiri dan orang lain perlu dikembangkan pada para anak/remaja. ${ }^{10}$

Secara garis besar Deklarasi memuat 10 asas tentang hak - hak anak yaitu hak untuk memperoleh perlindungan khusus, kesempatan dan fasilitas yang memungkinkan mereka berkembang secara sehat dan wajar dalam keadaan bebas dan bermanfaat, memiliki nama dan kebangsaan sejak lahir,mendapat jaminan sosial termasuk gizi yang cukup, perumahan rekreasi dan pelayanan kesehatan memperoleh pendidikan, perawatan dan perlakuan khusus jika mereka cacat, tumbuh dan dibesarkan dalam suasana yang penuh kasih dan rasa aman sedapat mungkin dibawah asuhan serta tanggung jawab orang tua mereka sendiri mendapat pendidikan, dan dalam hal terjadi kecelakaan/malapetaka, mereka termasuk yang pertama memperoleh perlindungan serta pertolongan, memperoleh perlindungan terhadap segala bentuk yang menyia-nyiakan (anak), kekejaman dan penindasan serta perbuatan yang mengarah kedalam bentuk diskriminasi. ${ }^{11}$

Ditinjau secara garis besar maka dapat disebutkan bahwa perlindungan anak dapat dibedakan dalam 2 pengertian ialah:

\footnotetext{
${ }^{9}$ Abdullah Nasih Ulwan, Pendidikan Anak dalam Islam, (Jakarta: Pustaka Amani,1995) hal. 148.

${ }^{10}$ Arif Gosita, Masalah Perlindungan Anak, (Jakarta: PT.Bhuana Ilmu Populer, 2004), hal. 3.

${ }^{11}$ Irma Setyowati Soemitro, Aspek Perlindungan Anak, (Jakarta: Bumi Aksara, 1990), hal. 12.
} 
1. Perlindungan yang bersifat yuridis, yang meliputi:perlindungan dalam:

a. Bidang hukum publik

b. Bidang hukum keperdataan

2. Perlindungan yang bersifat non yuridis,meliputi:
a. Bidang sosial
b. Bidang kesehatan
c. Bidang pendidikan ${ }^{12}$

Dikota - kota besar dan di daerah perbatasan kota banyak anak yang tumbuh dalam lingkungan yang tidak sesuai dengan proses pembentukan pribadi mereka, sehingga sering sekali terjadi kenakalan anak. Hal ini terjadi karena mereka lepas dari kendali, pengawasan dan pertumbuhan mental di luar pengamatan orang tua atau walinya.

Untuk mengikuti gaya hidup anak masa kini,tanpa memperhitungkan resiko mereka telah terperangkap dalam:

1. Eksploitasi fisik, diantaranya seperti:

a. Pekerja/buruh anak di sektor industri atau perusahaan yang berbahaya.

b. Pengemisan anak terlantar(anak jalanan)

2. Eksploitasi seksual, diantaranya seperti:

a. Prostitusi anak

b. Sodomi anak. ${ }^{13}$

Hal ini menyebabkan para orang tua selalu mengingatkan anaknya agar selalu berhati-hati terhadap orang yang tidak dikenal dan yang mempunyai wajah seperti penjahat. Para orang tua juga mengingatkan anak-anaknya agar tidak menerima pemberian apapun dari orang yang tidak dikenal. Ironisnya, saat ini di Indonesia sangat marak akan kasus pencabulan yang dilakukan oleh orang-orang terdekat. Akhirnya mitos-mitos pencabulan di Indonesia, seperti pelakunya adalah orang-orang tak dikenal, korban selalu berpakaian seksi, dan dilakukan pada malam hari ternyata harus dipatahkan

\footnotetext{
${ }^{12}$ Ibid., hal. 13.

${ }^{13}$ Ibid, hal. 17
} 
oleh kenyataan bahwa pencabulan di Indonesia saat ini justru lebih banyak dilakukan oleh orang-orang yang justru dihormati oleh anak-anak yang jadi korbannya, seperti kakek, ayah kandung, kakak kandung, ayah tiri, guru sekolah, guru agama, pengelola asrama, pendamping kegiatan, atau orangorang dewasa lain di sekitar korban yang seharusnya justru dapat menjadi contoh dan pelindung anakanak itu. Tidak jarang tindak pencabulan ini dilakukan justru pada siang hari ketika ibu si korban tidak ada di rumah. Pencabulan merupakan suatu perwujudan tidak sempurnanya rasa tanggung jawab dari seseorang terhadap sesama manusia.

Pencabulan adalah suatu hasil interaksi akibat adanya suatu interelasi antara fenomena yang ada dan saling mempengaruhi. Sekarang yang penting adalah memahami fenomena mana saja yang mempengaruhi eksistensi pencabulan tersebut. Hal ini adalah penting berhubung dengan penentuan siapa atau apa saja yang harus ditangani dalam menghadapi dan mengatasi permasalahan pencabulan ini. ${ }^{14}$ Selain itu pencabulan pada umumnya dilandasi oleh rasa tertekan dalam mewujudkan ekspresi seksual, disamping terdapat unsur-unsur tertentu lainnya seperti balas dendam atau sakit jiwa, penyebab lain terjadinya pencabulan oleh seseorang terhadap anak adalah karena pengaruh aspek struktural yaitu situasi dalam masyarakat yang semakin kompleks. Masalah pencabulan dalam lingkungan keluarga ini bukan menjadi rahasia lagi, hal ini terbukti dengan adanya pemberitaan di media massa yang memuat kasuskasus pencabulan seperti ini sulit untuk diungkap karena masih dianggap tabu untuk disebarluaskan, dan jika sampai diceritakan pada orang lain berarti akan membawa aib bagi keluarga. Pencabulan merupakan kejahatan yang sangat meresahkan masyarakat dan mempunyai tingkat keseriusan yang tinggi dan mengundang fear of crime (ketakutan pada kejahatan) dalam masyarakat, yang menyebabkan masyarakat merasa tidak aman. Pencabulan merupakan kejahatan seks atau perzinahan, yang dinyatakan oleh Syariat Islam sebagai

${ }^{14}$ Arief Gosita, Masalah Korban Kejahatan (Kumpulan karangan), Edisi Kedua, (Jakarta: Akademika Pressindo, 1993), hlm. 47. 
perbuatan melanggar hukum, yang layak dijatuhi hukuman maksimal, karena membawa akibat yang buruk, mengundang kejahatan dan dosa. ${ }^{15}$. Pencabulan termasuk juga bersetubuh telah tercakup di dalamnya. Menurut Pasal 81 ayat (1) Undang-undang Republik Indonesia No.23 Tahun 2002 Tentang Perlindungan Anak, terdapat hubungan antara si pembuat cabul dengan orang yang dicabuli.

Hubungan yang terdapat pada kasus tindak pidana pencabulan ini adalah hubungan kekeluargaan dimana si pembuat memiliki kewajiban hukum untuk melindungi, menghidupi, memelihara, mendidiknya, dan hubungan ini dipandang mempermudah pelaksanaan kejahatan. ${ }^{16}$ Pencabulan terhadap anak dibawah umur yang dilakukan oleh orang yang tidak memiliki hubungan sangatlah memprihatinkan, ironisnya ibu atau orang tua korban ikut menyaksikan pembuatan konten porno yang dilakukan oleh orang yang tidak dikenal,dengan anak tersebut. Kejahatan ini merupakan bentuk kejahatan seks yang sangat meresahkan masyarakat pada umumnya dan keluarga khususnya.

Bagaimana ia memulai? Semula ia membuat foto mesum dengan subyek foto anak kecil berinisial Dn (9) dengan perempuan bernama Apriliana alias Intan (28) di sebuah hotel dengan pakaian lengkap. Pertemuan kedua, Apriliana ini melakukan sesi foto hanya memakai celana dalam dan bra bersama Dn. Dn mendapat imbalan Rp 300 ribu dan Apriliana mendapat total imbalan sebesar Rp 1.6 juta dalam dua kali pertemuan. Foto-foto itu kemudian diunggah di akun komunitas Facebook bernama Vika yang isinya terdapat warga negara asing (WNA) asal Rusia berinisial R dan N asal Kanada. Dua WNA ini belakangan jadi berperan sebagai pemesan video porno. Kapolda Jabar menuturkan, Pengakuan Faisal dia diminta R dan $\mathrm{N}$ untuk membuat video porno anak-anak dan perempuan dewasa. Hingga akhirnya, pada pertemuan ketiga sekitar Mei tahun lalu, Apriliana

\footnotetext{
${ }^{15}$ M. Ali Chasan Umar, Kejahatan Seks dan Kehamilan Di Luar Nikah, Cetakan 1, (Jakarta: CV Panca Agung, 1990), hlm. 26.

16 Indonesia, Undang-Undang Republik Indonesia Nomor 23 Tahun 2002 tentang Perlindungan Anak. LN No. 109 Tahun 2002. TLN No. 4235
} 
datang kembali dengan Dn ke di Hotel Mitra yang sudah ditunggu oleh Faisal.

Awalnya, sang bocah berinisial Dn ini enggan melakukan adegan video porno apalagi direkam. Lantas Faisal kemudian menelpon orang tua Dn bernama Susanti untuk datang ke hotel. Faisal kemudian meminta Susanti untuk menyuruh anaknya beradegan mesum dengan Apriliana dengan menghadirkan teman dekat Dn berinisial Sp (11) agar menemani beradegan mesum. Perekaman video mesum pun dimulai di ruangan kamar hotel Idea's. Saat perekaman video, Susanti hadir menyaksikan anaknya beradegan mesum dengan diarahkan oleh Faisal. Apriliana mendapat imbalan sebesar Rp 1 juta, Dn mendapat Rp 300 ribu dan Sp sebesar Rp 100 ribu. Produksi video mesum pertama yang dibuat Mei 2017 itu kemudian dikirim ke $\mathrm{R}$ dan $\mathrm{N}$ via aplikasi pesan instan Telegram. $\mathrm{R}$ dan $\mathrm{N}$ kemudian diminta lagi untuk membuat video serupa.Akhirnya, dibuatlah video mesum kedua oleh Faisal sebagai pengarah pada Agustus 2017 dengan difasilitasi oleh Sri Mulyati alias Cici (36) sebagai perekrut perempuan bernama Imelda Oktaviani alias Imel (27).

Perempuan benama alias Cici menawarkan pada Imel untuk membuat video porno di Hotel Mitra bersama anak berinisial Rd (9) anak dari seorang ibu bernama Herni. Di hotel ini, adegan mesum dilakukan mulai dari balkon kamar hotel dengan direkam dan diarahkan oleh Faisal. Herni hadir di kamar hotel itu saat perekam. Imel mendapat imbalan sebesar Rp 1.5 juta, orangtua $\mathrm{Rd}$ bernama Herni mendapat $\mathrm{Rp} 500$ ribu dan Cici mendapat Rp 1 juta. Tidak lama kemudian, video mesum Imel dengan Rd menyebar. Dia kemudian meminta ganti rugi pada Faisal. Faisal dan Imel ini akhirnya bertemu dan Imel diberi uang ganti rugi s ebesar Rp 2.7 juta dan biaya Rp 500 ribu untuk mengubah tato d paha kiri. Total Rp 3.2 juta yang diterima Imel ini diberikan lagi ke Cici sebesar Rp 250 ribu dan Rp 150 ribu untuk orang tua Rd. Semua pihak yang terlibat dalam kasus ini, sebanyak tujuh orang sudah ditetapkan sebagai tersangka. 
Enam orang sudah ditangkap dan satu lagi bernama Ismi berperan sebagai penghubung masuk daftar pencarian orang (DPO). Dalam kasus anak, tersangka dijerat Pasal 81 Undang-undang Perlindungan Anak. ${ }^{17}$

\section{B. Rumusan Masalah}

Berdasarkan uraian yang telah penulis kemukakan dalam bagian latar belakang, maka penulis merumuskan bahwa pokok permasalahan untuk dibahas dan di analisis dalam penelitian skripsi ini adalah:

1. Bagaimana penerapan sanksi UU ITE (Informasi Transaksi Elektronik) terhadap pelaku pembuatan foto dan video pencabulan anak?

\section{Metode Penelitian}

Metode penelitian yang digunakan dalam penelitian ini adalah menggunakan metode penelitian normatif, pengumpulan datanya menggunakan studi kepustakaan dan wawancara. Dalam penelitian hukum normatif, penulis menggunakan data sekunder, yaitu data yang sudah ada sebelumnya berupa dokumen-dokumen resmi, buku-buku,hasil penelitian yang berwujud laporan, dan lain-lain, yang jenis datanya (bahan hukum)terdiri dari: ${ }^{18}$

\section{Bahan Hukum Primer}

Bahan hukum primer merupakan bahan-bahan hukum yang mengikat dan berlaku umum yang bersifat autoriatif yang berarti otoritas. Bahanbahan hukum primer terdiri dari perundang-undangan, catatan-catatan resmi atau risalah - risalah dalam pembuatan perundang-undangan dan putusan - putusan hakim. $^{19}$ Dalam penulisan skiripsi ini penulis memperoleh data yang diperlukan melalui penelitian kepustakaan, yang meliputi:

17 http://jabar.tribunnews.com/2018/01/08/kronologi-pembuatan-video-mesum-perempuandewasa-dengan-bocah-ternyata-sang-bocah-sempat-menolak

18 Soerjono Soekanto, Pengantar Penelitian Hukum, (Jakarta: Universitas Indonesia, 1984).hal. 170.

${ }^{19}$ Ibid., hal. 141. 
2. Bahan/sumber primer, yaitu peraturan perundang-undangan seperti:

a. Kitab Undang-undang Hukum Pidana ;

b. Kitab Undang-undang Perlindungan Anak (UU No.23 Tahun 2002);

c. Undang-undang Informasi Transaksi Elektronik (UU No 19 Tahun 2016 jo.UU No.11 Tahun 2008)

3. Bahan/Sumber Sekunder,

Bahan hukum sekunder meliputi memberikan penjelasan mengenai badan hukum primer, seperti buku ilmu pengetahuan, dan berbagai artikel yang berkaitan dengan penulisan ini.

4. Bahan/Sumber Tertier

Kamus Bahasa Indonesia terbitan Balai Pustaka Sifat penulisan ini adalah deskriptif yaitu suatu metode yang mengambil data secara tertulis untuk diuraikan sehingga memperoleh gambaran serta pemahaman secara menyeluruh. Skripsi ini dianalisis secara kualitatif yaitu menjelaskan mengenai proses penerapan sanksi pidana terhadap korban pencabulan terhadap anak, namun orang tua korban membolehkan anaknya untuk berhubungan badan dengan perempuan dewasa.

Penelitian ini menggunakan pendekatan secara kualitatif, maka data yang dikumpulkan secara kualitatif. Analisis kualitatif adalah tata cara penelitian yang menghasilkan data deskriptif, yaitu untuk mendapatkan jawaban dalam masalah penelitian ini. ${ }^{20}$

\section{PEMBAHASAN}

\section{A. Kasus Posisi}

Kasus ini bermula dari sebuah foto mesum dengan subyek foto anak kecil berinisial Dn (9) dengan perempuan bernama Apriliana alias Intan (28) di sebuah hotel dengan pakaian lengkap.Pertemuan kedua, Apriliana ini melakukan sesi foto hanya memakai celana dalam dan bra bersama Dn.Dn mendapat imbalan $\mathrm{Rp} 300$ ribu dan Apriliana mendapat total imbalan sebesar Rp 1.6 juta dalam dua kali pertemuan.

\footnotetext{
${ }^{20}$ Soerjono Soekanto, Op., Cit, hal. 32.
} 
Foto-foto itu kemudian diunggah di akun komunitas Facebook bernama Vika yang isinya terdapat warga negara asing (WNA) asal Rusia berinisial $\mathrm{R}$ dan $\mathrm{N}$ asal Kanada.Dua WNA ini belakangan jadi berperan sebagai pemesan video porno. "Pengakuan Faisal, dia diminta $\mathrm{R}$ dan $\mathrm{N}$ untuk membuat video porno anak-anak dan perempuan dewasa. Lalu pada pertemuan ketiga sekitar Mei tahun lalu, Apriliana datang kembali dengan Dn ke di Hotel Mitra yang sudah ditunggu oleh Faisal.

Awalnya, sang bocah berinisial Dn ini enggan melakukan adegan video porno apalagi direkam.Lantas Faisal kemudian menelpon orang tua Dn bernama Susanti untuk datang ke hotel.Faisal kemudian meminta Susanti untuk menyuruh anaknya beradegan mesum dengan Apriliana dengan menghadirkan teman dekat Dn berinisial Sp (11) agar menemani beradegan mesum.Perekaman video mesum pun dimulai di ruangan kamar hotel Idea's."Saat perekaman video, Susanti hadir menyaksikan anaknya beradegan mesum dengan diarahkan oleh Faisal. Apriliana mendapat imbalan sebesar Rp 1 juta, Dn mendapat Rp 300 ribu dan Sp sebesar Rp 100 ribu," kata Kapolda.

Produksi video mesum pertama yang dibuat Mei 2017 itu kemudian dikirim ke $\mathrm{R}$ dan $\mathrm{N}$ via aplikasi pesan instan Telegram. $\mathrm{R}$ dan $\mathrm{N}$ kemudian diminta lagi untuk membuat video serupa.Akhirnya, dibuatlah video mesum kedua oleh Faisal sebagai pengarah pada Agustus 2017 dengan difasilitasi oleh Sri Mulyati alias Cici (36) sebagai perekrut perempuan bernama Imelda Oktaviani alias Imel (27).

Perempuan benama alias Cici menawarkan pada Imel untuk membuat video porno di Hotel Mitra bersama anak berinisial Rd (9) anak dari seorang ibu bernama Herni.Di hotel ini, adegan mesum dilakukan mulai dari balkon kamar hotel dengan direkam dan diarahkan oleh Faisal. Herni hadir di kamar hotel itu saat perekam."Imel mendapat imbalan sebesar Rp 1.5 juta, orangtua Rd bernama Herni mendapat Rp 500 ribu dan Cici mendapat Rp 1 juta, tidak lama kemudian, video mesum Imel dengan Rd menyebar. Dia kemudian meminta ganti rugi pada Faisal. 
Faisal dan Imel ini akhirnya bertemu dan Imel diberi uang ganti rugi sebesar Rp 2.7 juta dan biaya Rp 500 ribu untuk mengubah tato d paha kiri."Total Rp 3.2 juta yang diterima Imel ini diberikan lagi ke Cici sebesar Rp 250 ribu dan Rp 150 ribu untuk orang tua $\mathrm{Rd}$, Semua pihak yang terlibat dalam kasus ini, sebanyak tujuh orang sudah ditetapkan sebagai tersangka. Namun warga negara asing yang merupakan pemesan dari pembuatan konten porno tersebut, belom juga di tangkap masih dalam tahap penyelidikan melalui interpol dan penyelidikannya masih ditangani oleh bareskrim.

\section{B. Hasil Wawancara dengan Kepala Unit Perlindungan Perempuan dan Anak (KANIT PPA)Polisi Daerah Jawa Barat}

Kepala Unit Perlindungan Perempuan dan Anak juga menambahkan. Bahwa kasus ini pertama kali didapat dari masyarakat melalui media sosial ketika dibuka link tersebut merupakan video porno, kemudian polisi melakukan penyelidikan terhadap perkara.

Untuk kasus ini sendiri sudah masuk tahap ke 2, berkas perkara sudah dinyatakan lengkap hasil penyidikan oleh jaksa dan masuk P21 pada hari senin tanggal 3 Mei 2018. Untuk pasal yang dikenakan yakni UU ITE, Pornografi dan Perlindungan Anak.

Maksut dan tujuan para pelaku berawal dari sekedar coba-coba, lalu mendapatkan respon dan menghasilkan sejumlah uang. Lalu dari situlah para pelaku memulai bisnis haram ini. Tujuan utamanya yakni untuk mencari uang dari hasil konten tersebut, yang biayanya sebesar kurang lebih 180 juta rupiah.

Dalam kasus ini alfa lah yang pertama kali mendistribusikan konten tersebut. Dialah yang membuat, dia juga yang membuat, dan dia juga yang mencari pemain melalui rekannya Cici melalui susan, Cici melalui Herni.

Untuk korban sudah berada di rumah sosial, untuk trauma yang dialami korban sudah mulai pulih kembali melalui bantuan psikiater yang ada. Untuk sementara anak tersebut di bina oleh negara. 
Selain itu upaya kepolisian agar video tersebut tidak menyebar yakni menutup atau memblokir link mengenai konten tersebut bekerjasama dengan Kominfo.

\section{Hasil Wawancara dengan Dosen Fakultas Teknologi Informasi (mata kuliah Information Security)}

Narasumber kedua penulis yakni adalah seorang akademis Fakultas Teknik Informasi yang merupakan dosen dengan matakuliah Information Security. Beliau menjelaskan tentang bagaimana pemerintah menangani suatu konten video porno.

Dia menuturkan jika seseorang menyebarkan video porno, tidak sepenuhnya kita meyalahkan pihak aplikasi tersebut. Contoh dalam kasus ini pelaku menyebarkan melalui via telegram, lalu bukan dari pihak telegram lah yang sepenuuhnya salah. Dan juga data ataupun isi dari telegram tersebut merupakan privasi seseorang. Jika secara security itu tidak aman jika dari pihak aplikasi bisa membaca isi data dari file aplikasi tersebut. Upaya pemerintah dalam menangani kasus penyebaran konten video porno yakni bekerja sama dengan pihak provider dengan cara pemblokiran terhadap konten.Jika untuk membatasi atau mencegah video porno bisa dikatakan susah. Jika semisal Indonesia memiliki paham seperti korea utara mungkin bisa dalam membatasi penyebaran.

Undang- Undang ITE bisa dikatakan kurang efektif dalam pemberantasan penyebaran video porno tersebut.Seperti halnya teroris, Badan Intelejen Negara bisa membaca tetapi setelah kejadian tersebut terjadi.

\section{Hasil Wawancara dengan Badan Siber dan Sandi Negara}

Hasil wawancara penulis dengan Badan Siber dan Sandi Negara telah membuahkan hasil, namun tidak menemukan jalan keluar dari permasalahan yang penulis angkat. Berikut adalah hasil rekapan wawancara penulis 
dengan Bapak Y.B.Susilo Wibowo, S.E, M.M selaku Kepala Biro Hukum dan Hubungan Masyarakat.

Hasil wawancara dengan Badan Siber dan Sandi Negara yakni. Menanyakan bagaimana upaya Badan Siber dalam menangani sebuat kejahatan siber pada video porno. Badan siber telah menjelaskan yakni BSSN mempunyai tugas menjaga ranah siber dalam keadaan aman dan mampu diakses oleh seluruh pengguna dengan baik, adanyan penyebaran konten negatif oleh pengguna internet akan berhadapan langsung dengan aparat penegak hukum.

\section{E. Analisis Yuridis}

Delik pornografi melalui internet tidak diatur secara khusus dalam KUHPidana. Dalam KUHPidana juga tidak dikenal istilah pornografi.Namun, terdapat pasal KUHPidana yang bisa dikenakan untuk perbuatan mengenai delik tersebut, yakni Pasal 282 KUHPidana mengenai kejahatan kesusilaan.

"Barangsiapa menyiarkan, mempertontonkan atau menempelkan dengan berterang - terangan suatu tulisan yang diketahui isinya, atau suatu gambar atau barang yang dikenalnya yang melanggar perasaan kesopanan, maupun membuat, nembawa masuk, mengirimkan langsung, membawa keluar atau menyediakan tulisan, gambar atau barang itu untuk disiarkan, dipertontonkan atau ditempelkan sehingga kelihatan oleh orang banyak, ataupun dengan berterang - terangan atau dengan menyiarkan sesuatu surat, ataupun dengan berterang - terangan diminta atau menunjukkan bahwa tulisan, gambar atau barang itu bileh didapat, dihukum penjara selama lamanya satu tahun empat bulan atau denda sebanyak - banyaknya Rp 45.000.'Dalam UU No.11 Tahun 2008 tentang informasi dan Transaksi Elektronik juga tidak ada istilah pornografi, tetapi "muatan yang melanggar kesusilaan”. Penyebaran muatan yang melanggar kesusilaan melalui internet diatur dalam Pasal 27 ayat (1) UU ITE mengenai Perbuatan yang dilarang, yaitu: 
"Setiap Orang dengan sengaja dan tanpa hak mendistribusikan dan/atau mentransmisikan dan/atau membuat dapat diaksesnya Informasi Elektronik dan/atau Dokumen Elektronik yang memiliki muatan yang melanggar kesusilaan.'Pelanggaran terhadap Pasal 27 ayat (1) UU ITE dipidana dengan penjara paling lama enam tahun dan/atau denda paling banyak Rp 1.000.000.000(Pasal 45 ayat (1) UU ITE). Dalam Pasal 53 UU ITE.Dinyatakan bahwa seluruh peraturan perundang-undangan yang telah ada sebelumnya dinyatakan tetap berlaku, selama tidak bertentangan dengan UU ITE tersebut.

Sementara itu Undang-undang yang secara tegas mengatur mengenai pornografi adalah UU No.44 Tahun 2008 tentang Pornografi. Pengertian pornografi menurut Pasal 1 angka 1 UU Pornografi adalah: “.... gambar, sketsa, ilustrasi, foto, tulisan, suara, bunyi, gambar bergerak, animasi, kartun, percakapan, gerak tubuh, atau bentuk pesan lainnya melalui berbagai bentuk media komunikasi dan/atau pertunjukan di muka umum, yang memuat kecabulan atau eksploitasi seksual yang melanggar norma kesusilaan dalam masyarakat."

Pelarangan penyebarluasan pornografi, termasuk melalui di internet, diatur dalam pasal 4 ayat 1 UU Pornografi yaitu : Setiap orang dilarang memproduksi, membuat, memperbanyak, menggandakan, menyebarluaskan, menyiarkan, mengimpor, mengekspor, menawarkan, memperjualbelikan, menyewakan, atau menyediakan pornografi yang secara eksplisit memuat:

1. persenggamaan, termasuk persenggamaan yang menyimpang;

2. kekerasan seksual;

3. masturbasi atau onani;

4. ketelanjangan atau tampilan yang mengesankan ketelanjangan;

5. alat kelamin; atau

6. pornografi anak

Pelanggaran pasal 4 ayat (1) UU Pornografi diancam pidana penjara paling singkat 6 bulan dan paling lama 12 tahun dan/atau pidana denda paling sedikit 250 juta rupiah dan paling banyak 6 milyar(Pasal 29 UU 
Pornografi). Pasal 44 UU Pornografi dinyatakan tetap berlaku sepanjang tidak bertentangan dengan Undang-Undang ini.

\section{F. Hasil Analisis Penulis}

Peraturan perundang-undangan yang dapat diterapkan terhadap pelaku pornografi yang tersebar luas di masyarakat minimal harus dilihat dari dua aspek, yaitu antara lain: ${ }^{21}$

1. Aspek waktu atau masa pembuatan benda pornografi itu dilakukan;

2. Aspek waktu atau masa penyebarluasan benda pornografi di masyarakat. Adapun peraturan perundang-undangan yang menjadi dasar hukum yang dapat diterapkan terhadap pelaku pornografi, yaitu antara lain:

1. Pasal 282 ayat (1) KUHPidana;

2. Pasal 282 ayat (1) KUHPidana jo. Pasal 55 ayat (1) ke-1 KUHPidana

3. Pasal 27 ayat (1) jo. Pasal 45 UU No.11 Tahun 2008 tentang Informasi dan Transaksi Elektronik;

4. Pasal 4 ayat (1) jo. Pasal 29 UU No.44 Tahun 2008 tentang Pornografi;

5. Pasal 6 jo. Pasal 32 UU No.44 Tahun 2008 tentang pornografi;

6. Pasal 8 jo. Pasal 34 UU No.44 Tahun 2008 tentang Pornografi;

7. Pasal 9 jo. Pasal 35 UU No.44 Tahun 2008 tentang Pornografi;

Untuk masuk dalam pembahasan mengenai penjatuhan sanksi pidana terhadap pelaku penyebaran maupun pembuat video porno. Perlu diketahui mengenai posisi kasus. Perbuatan terdakwa sebagaimana diatur dan diancam pidana dalam ketentuan Pasal 27 Jo. Pasal 45 ayat (1) UU RI ITE No. 11 tahun 2008 Jo. Pasal 55 ayat(1) ke-1 KUHPidana. Pasal 27 ayat (1) UU RI ITE

Setiap Orang dengan sengaja dan tanpa hak mendistribusikan dan/atau mentransmisikan dan/atau membuat dapat diaksesnya Informasi Elektronik dan/atau Dokumen Elektronik yang memiliki muatan yang melanggar kesusilaan.

${ }^{21}$ Neng Djubaedah, Pornografi dan Pornoaksi, (Jakarta:Prenada Media Group 2003), hlm. 
Pasal 45 ayat (1) UU RI ITE "Setiap Orang yang memenuhi unsur sebagaimana dimaksud dalam Pasal 27 ayat (1), ayat (2), ayat (3), atau ayat (4) dipidana dengan pidana penjara paling lama 6 (enam) tahun dan/atau denda paling banyak Rp1.000.000.000,00 (satu miliar rupiah)"

Pasal 55 ayat (1) ke-1 "Mereka yang melakukan, yang menyuruh melakukan, dan yang turut serta melakukan perbuatan."

Penjelasaan unsur-unsur dari dakwaan di atas yang didakwakan Penuntut Umum sebagai berikut :

1. Unsur barang siapa Unsur setiap orang sebagai subyek hukum dapat terpenuhi jika orang yang melakukan perbuatan. Jadi jelas arti barang siapa disini yang dimaksudkan adalah Terdakwa I Muhammad Feisal Akbar alias Alfa, sebagaimana identitasnya yang telah diuraikan, bahwa benar para tersangka merekam alat kemaluan Imelda dengan seorang anak dibawah umur karenanya unsur ini telah terbukti secara sah dan meyakinkan;

2. Unsur dengan sengaja dan tanpa hak mendistribusikan dan/atau mentransmisikan dan/atau membuat dapat diaksesnya Informasi Elektronik dan/atau Dokumen Elektronik yang memiliki muatan yang melanggar kesusilaan. Yang dimaksud dengan unsur ini adalah karena perbuatan dengan sengaja dan tanpa hak mendistribusikan dan/atau membuat dapat diaksesnya informasi elektronik dan/atau dokumen elektronik yang memiliki muatan yang melanggar kesusilaan. Dilain hal Warga Negara Asing yang merupakan seorang pemesan video porno tersebut bisa juga disebut sebagai penyebar konten tersebut. Namu pihak kepolisian yang bekerjasama dengan interpol masih terus mendalami kasus ini, dan masih mencari warga negara asing tersebut.

3. Unsur orang yang melakukan, yang menyuruh melakukan atau turut serta melakukan perbuatan itu. Yang dimaksud dengan turut melakukan (medepleger) dalam arti kata bersama-sama melakukan, sedikitnya ada dua orang. Yaitu orang yang melakukan (pleger) dan orang yang turut 
melakukan (medepleger) peristiwa tersebut. Jadi kedua orang tersebut secara bersama-sama melakukan unsur dari tindak pidana tersebut.

Untuk memperjelas pembahasan ini, maka asumsi penulis ialah:

1. yang dimaksud "membuat foto atau video porno untuk dinikmati sendiri" ialah foto atau rekaman video hubungan seksual antara pria dan wanita itu sendiri.

2. Pria dan wanita tidak termasuk dalam kategori anak sebagaimana dimaksud dalam perundang-undangan.

\section{G. Definisi dan Ruang Lingkup Pornografi}

Berbicara mengenai pornografi, telah ada beberapa undang-undang yang mengatur substansi yang dimaksud, antara lain:

1. Kitab Undang-Undang Hukum Pidana (“KUHP”);

2. Undang-Undang No. 11 Tahun 2008 tentang Informasi dan Transaksi Elektronik (“UU ITE”); dan

3. Undang-Undang No. 44 Tahun 2008 tentang Pornografi (“UU 44/2008”)

Dalam Bab - XIV KUHP diatur tentang Kejahatan terhadap Kesusilaan, tetapi tidak diatur mengenai definisi kesusilaan. Demikian juga dengan UU ITE. Pasal 27 ayat (1) UU ITE mengatur larangan mendistribusikan, mentransmisikan, dan/atau membuat dapat diaksesnya Informasi atau Dokumen Elektronik yang memiliki muatan yang melanggar kesusilaan. Dari ketiga undang-undang yang dimaksud, UU 44/2008 lebih jelas memberikan definisi mengenai Pornografi, yaitu gambar, sketsa, ilustrasi, foto, tulisan, suara, bunyi, gambar bergerak, animasi, kartun, percakapan, gerak tubuh, atau bentuk pesan lainnya melalui berbagai bentuk media komunikasi dan/atau pertunjukan di muka umum, yang memuat kecabulan atau eksploitasi seksual yang melanggar norma kesusilaan dalam masyarakat. Oleh karena itu, definisi tersebut dapat diterapkan dalam pembahasan ini.

Secara teoritis-normatif, foto atau rekaman video hubungan seksual disebut Pornografi apabila foto atau rekaman tersebut melanggar norma 
kesusilaan dalam masyarakat. Pasal 4 ayat (1) UU 44/2008 mengatur larangan perbuatan memproduksi, membuat, memperbanyak, menggandakan, menyebarluaskan, menyiarkan, mengimpor, mengekspor, menawarkan, memperjualbelikan, menyewakan, atau menyediakan pornografi yang secara eksplisit memuat:

1. persenggamaan, termasuk persenggamaan yang menyimpang;

2. kekerasan seksual;

3. masturbasi atau onani;

4. ketelanjangan atau tampilan yang mengesankan ketelanjangan;

5. alat kelamin; atau

6. pornografi anak

Pasal 4 ayat (1) UU 44/2008 tentang Pornografi disebutkan bahwa yang dimaksud dengan "membuat" adalah tidak termasuk untuk dirinya sendiri dan kepentingan sendiri.

\section{H. Pembuatan Pornografi}

Dalam hal pria dan wanita saling memberikan persetujuan untuk perekaman video seksual mareka dan foto serta video tersebut hanya digunakan untuk kepentingan sendiri sebagaimana dimaksud dalam pengecualian dalam Pasal 44/2008 maka tindakan pembuatan dan penyimpanan yang dimaksud tidak termasuk dalam ruang lingkup “membuat” sebagaimana dimaksud dalam Pasal 4 UU Pornografi.

Dalam hal pria atau wanita melakukan pengambilan gambar atau perekaman hubungan seksual mereka tanpa diketahui oleh wanita atau pria pasangannya, atau tanpa persetujuannya, maka pembuatan video tersebut melanggar Pasal 4 ayat (1) UU 44/2008. Persetujuan (consent) merupakan bagian yang sangat vital dalam menentukan adanya pelanggaran atau tidak.

\section{Diseminasi atau Distribusi Pornografi}

Dalam hal pembuatan foto atau video disetujui oleh para pihak maka penyebaran oleh salah satu pihak dapat membuat pihak lain terjerat 
ketentuan pidana, sepanjang pihak itu tidak secara tegas memberikan larangan untuk penyebarannya.

Sebagai contoh apabila pria dan wanita sepakat atau saling memberikan persetujuan untuk pembuatan foto atau rekaman Pornografi, kemudian pria menyebarkan Pornografi, tetapi wanita sebelumnya tidak memberikan pernyataan tegas untuk melarang pria untuk menyebarkan atau mengungkap Pornografi tersebut maka wanita dapat terjerat tindak pidana penyebaran Pornografi.

Apabila wanita sebelumnya telah memberikan pernyataan tegas bahwa ia setuju membuat pornografi tetapi tidak mengizinkan pria untuk mengungkap atau menyebarkan Pornografi tersebut maka wanita memiliki posisi yang lebih kuat untuk tidak dipersalahkan sebagai turut serta penyebaran pornografi.

Demikian juga apabila wanita memang sejak awal tidak mengetahui adanya pembuatan foto atau video Pornografi, atau tidak memberikan persetujuan terhadap pembuatan Pornografi tersebut, maka dalam hal ini, wanita tersebut dapat disebut sebagai korban penyebaran konten Pornografi.

\section{J. Penyimpanan Produk Pornografi}

Pasal 6 UU 44/2008 mengatur bahwa setiap orang dilarang..., memiliki, atau menyimpan produk pornografi sebagaimana dimaksud dalam Pasal 4 ayat (1), kecuali yang diberi kewenangan oleh peraturan perundangundangan.

Menimbulkan pertanyaan apakah video atau foto Porno tersebut yang dibuat oleh pria dan wanita juga dilarang?

Salah satu interpretasi yang mungkin ialah sebagai berikut.

1. Dalam hal pria dan wanita telah saling memberikan persetujuan terlebih dahulu maka penyimpanan atau pemilikan Pornografi tersebut menjadi bagian yang tidak terpisahkan dalam proses membuat dan hal ini masuk dalam kategori pengecualian yang dimaksud dalam Penjelasan Pasal 4 ayat (1) UU 44/2008. 
Secara teknis, umumnya, setelah video atau foto dibuat, secara otomatis akan disimpan dalam sistem penyimpanan yang ada di dalam media elektronik. Oleh karena itu, secara hukum, apabila dalam satu kesatuan proses, menjadi tidak logis apabila pembuatan diperbolehkan tetapi penyimpanan atau pemilikan dilarang.

2. Apabila dalam hal salah satu pihak tidak memberikan persetujuan terlebih dahulu, maka penyimpanan atau pemilikannya menjadi dilarang sebagaimana dimaksud dalam Pasal 6 UU 44/2008.

\section{K. Memfasilitasi Pornografi}

Pasal 7 UU 44/2008 mengatur bahwa setiap orang dilarang mendanai atau memfasilitasi perbuatan sebagaimana dimaksud dalam Pasal 4.

Apakah tindakan pria atau wanita yang memberikan persetujuan kepada wanita atau pria dalam pembuatan pornografi termasuk memfasilitasi Pornografi?

Interpretasi yang mungkin ialah bahwa sepanjang wanita atau pria yang telah memberikan persetujuan itu terlibat di dalam foto atau video pornografi tersebut maka, ia tidak dapat dianggap sebagai memfasilitasi perbuatan Pornografi.

\section{Penyebaran Pornografi}

Pasal 27 ayat (1) UU ITE mengatur:

"Setiap Orang dengan sengaja dan tanpa hak mendistribusikan dan/atau mentransmisikan dan/atau membuat dapat diaksesnya Informasi Elektronik dan/atau Dokumen Elektronik yang memiliki muatan yang melanggar kesusilaan."

Ancaman pidana terhadap pelanggar diatur dalam Pasal 45 ayat (1) UU ITE, yaitu ancaman pidana penjara paling lama 6 (enam) tahun dan/atau denda paling banyak 1 (satu) milliar rupiah.

Pasal 4 ayat (1) UU Pornografi menyebutkan:

"Setiap orang dilarang..., membuat,...menyebarluaskan... Pornografi..." 
Ancaman terhadap pasal ini diatur dalam Pasal 29 UU 44/2008 yaitu pidana penjara paling singkat 6 (enam) bulan dan paling lama 12 (dua belas) tahun dan/atau pidana denda paling sedikit Rp 250 juta rupiah dan paling banyak Rp 6 miliar rupiah.

Dengan demikian, dalam kasus atau permasalahan yang rekan telah dibahas, dalam kasus ini hakim dapat menerapkan sebagian atau keseluruhan pasal-pasal terkait aspek pembuatan, distribusi, penyimanan, fasilitas, dan/atau penyebaran konten pornografi sebagaimana kami uraikan di atas.

\section{Penutup}

\section{A. Kesimpulan}

Bertolak pada pembahasan dan hasil penelitian yang telahm dikemukakan penulis, maka dapat ditarik kesimpulan sebagai berikut :

1. Dasar hukum terhadap pelaku penayangan pornografi diatur dalam UU Pornografi, UU ITE dan KUHPidana. Dalam kasus seperti ini

2. Pertanggungjawaban pidana terhadap penayangan pornografi dalam kasus ini, lebih tepatnya menuntut terdakwa melanggar ketentuan yang diatur dalam Pasal 27 ayat (1) Jo. Pasal 45 ayat (1) Jo. Pasal 55 ayat (1) ke-1 KUHPidana.

3. Faktor penyebab terjadinya kejahatan pornografi terhadap anak melalui media elektronik disebabkan oleh beberapa faktor yakni: faktor kejiwaan, faktor lingkungan, faktor ekonomi, serta faktor teknologi yang sangat berpengaruh. Penyebab dari luar (eksternal), yaitu mencakup lingkungan, ekonomi, dan teknologi yang membuat anak-anak merasa ingin mempelajarinya lebih dalam dan faktor penyebab dari dalam (internal), yaitu faktor kejiwaan karena adanya ketidakmampuan anak dalam melakukan penyesuaian sosial atau beradaptasi terhadap nilai dan norma yang ada di dalam masyarakat.

4. Upaya penanggulangan terjadinya kejahatan pornografi terhadap anak melalui media elektronik terdiri dari upaya penal dan non penal. 
Upaya penal terdiri dari dengan hukuman penjara, yang dimana saat putusan akhir si anak tetap di kembalikan kepada orangtua, tetapi jika si anak melakukannya kembali dengan berat hati si anak dimasukan kedalam penjara dengan kesalahan atas UU ITE yang dimana melanggar kesusilaan. Sedangkan upaya non penal terdiri dari adanya sosialisasi kesekolah-sekolah pada waktu upacara pagi yang dimana itu menjadi wadah atau tempatnya para anggota kepolisian untuk memberikan informasi terkait dengan apa yang ingin di informasikan.

\section{B. Saran}

Melihat dari hasil kesimpulan diatas, penulis mendapatkan beberapa saran sebagai berikut :

1. Diperlukan semua pihak yang terkait dengan kehidupan umat beragama, untuk benar-benar memahami betapa pentingnya ajaran agama.

2. Diperluka kerja sama antara pemerintah dan aparat penegak hukum dalam penanganan penyebaran konten video porno agar konten tersebut tidak menyebar;

3. Pemberian perhatian psikologis terhadap anak, agar anak tidak lagi mengalami trauma dari hal yang telah dia perbuat.

\section{Daftar Pustaka}

\section{A. BUKU}

Gosita, Arif. Masalah Perlindungan Anak. (Jakarta: PT.Bhuana Ilmu Populer, 2004).

Gunarsa, Singgih D. Psikologi Perkembangan Anak dan Remaja. (Jakarta: BPK Gunung Mulia, 2002).

Kartono, Kartini. Peran Orang Tua dalam Memandu Anak. (Jakarta: Rajawali Press, 1992).

Maskun. Kejahatan Siber Cyber Crime. (Jakarta:Prenada Media Group 2013). 
Soeaidy, Sholeh dan Zulkhair. Dasar Hukum Perlindungan Anak. (Jakarta: CV.Novindo Pustaka Mandiri,2001).

Soekanto, Soerjono. Pengantar Penelitian Hukum, (Jakarta: Universitas Indonesia, 1984).

Soemitro, Irma Setyowati. Aspek Perlindungan Anak. (Jakarta: Bumi Aksara, 1990).

Soesilo, R. Kitab Undang-Undang Hukum Pidana (KUHP) Serta Komentar-komentarnya Lengkap Pasal Demi Pasal. (Bogor: Politeia, 1995).

Ulwan, Abdullah Nasih. Pendidikan Anak dalam Islam. (Jakarta: Pustaka Amani,1995).

\section{B. PERATURAN UNDANG-UNDANG}

Indonesia. Undang-Undang Informasi dan Transaksi Elektronik (atau yang dikenal dengan Undang-Undang ITE)disahkan pada tanggal 21 April tahun 2008 memiliki 13 Bab dan 54 Pasal memberikan pengaturan dalam bidang informasi teknologi terutama dalam ruang lingkup cyberspace

. Undang-Undang Republik Indonesia Nomor 23 Tahun 2002

tentang Perlindungan Anak. LN No. 109 Tahun 2002. TLN No. 4235

\section{WEBSITE}

https://www.google.co.id/search?client=ms-android-

samsung\&q=ur.it. $/ \mathrm{kamal} /$ the + law + of + cyberspace $\&$ spell $=1 \&$ sa $=X \& v e$ d=0ahUKEwj_6IDI6fbaAhUL148KHSY9C1AQBQghKAA\&biw=360 $\underline{\text { bih }=612}$

https://tekno.kompas.com/read/2008/07/24/07303570/kejahatan.cyber.tin ggi.polisi.menerima.laporan.dari.17.negara

http://jabar.tribunnews.com/2018/01/08/kronologi-pembuatan-videomesum-perempuan-dewasa-dengan-bocah-ternyata-sang-bocahsempat-menolak 